RESEARCH ARTICLE

\title{
Carbon emission scenario of conventional buildings
}

\author{
Aojoy Kumar Shuvo*iD, Shayla Sharmin iD \\ Rajshahi University of Engineering \& Technology, Department of Building Engineering \& Construction \\ Management, Rajshahi, Bangladesh
}

\begin{abstract}
Life cycle assessment (LCA) is a very familiar methodology to measure the environmental effects of any products where all the process associated with the products from cradle to grave was analyzed and the possible emission to environment can be identified. In this study we applied LCA on three traditionally constructed reinforced concrete buildings (one five storied residential building, one three storied office building and one three storied educational building) where no environmental issues were considered during design and construction period. The aim of this research is to evaluate and compare energy consumption and carbon emissions of three different types of buildings from their materialization stage to the end-of-life stage. This paper also describes the step-by-step process of quantifying the overall carbon emission from a building systematically. There is an overview of how emission varies according to buildings material, construction process and objective of buildings. The result shows that the operational phase is mainly responsible for maximum carbon emission due to maximum energy consumption among three phases of life cycle assessment. However, it is also found from the study that the materialization and operation stages together contribute more than $97 \%$ of total emissions. Since a huge amount of operational energy is required for commercial building compare to other two buildings, it consumes energy comparatively higher than residential and educational building which results in $13.6 \%$ more emission than residential building and $19 \%$ more than educational building.
\end{abstract}

\section{Keywords}

Carbon emission; Life-cycle analysis; Energy consumption; Conventional buildings; Comparison

Received: 30 July 2021; Accepted: 23 September 2021

ISSN: 2630-5771 (online) C 2021 Golden Light Publishing All rights reserved.

\section{Introduction}

The devastating environmental changes like global warming, acidification, smog formation, ozone layer and natural resources depletion, biological diversity losses, waste accumulation, etc. are highlighting construction industry as a worldwide agitating sector. More than $40 \%$ of world's natural resources and energy are consumed by buildings and about $33 \%$ of the total carbon dioxide $\left(\mathrm{CO}_{2}\right)$ is emitted by buildings [1-3]. In the traditional method of construction of buildings which we called conventional buildings where the knowledge of construction passed on from generation to generation related to the wet construction system utilizing reinforced concrete, the consumption of energy and carbon emission are relatively high. To ensure a sustainable environment, we must ensure a low carbon society first. Therefore, in order to promote a low carbon society, it is desirable to quantify the total energy use during the entire life of a building in order to identify the possible ways

\footnotetext{
* Corresponding author

Email: aojoy.ce66@gmail.com
} 
of reducing carbon emissions. Each phase of a building-construction, operation, and finally demolition and disposal, affects environment depending on the type, location and purpose of use of each building [4]. The direct energy is mostly consumed at the construction and operation phase of a building considered in the earliest building's energy certification procedures. However, after witnessing a considerable rise in the indirect energy consumption in the construction phase, researchers starts paying more attention to the building materials' production and to the recycling of construction materials at its demolition [5]. To ensure a sustainable development with less environmental issues, rapid economic growth and social advances, it is obligatory to embrace a multidisciplinary approach which covers a series of traits including energy saving, better use of construction materials and water, reprocess and reutilizing of demolished materials and inhibiting emissions. In order to develop a sustainable building sector life cycle assessment (LCA) can be helpful to make decision by eliminating resource depletion crisis, verifying global environmental threats and energy requirement throughout the lifetime of a building. Each Building has a totally different complex product life cycle from others as they are made of several types of materials and material compositions. Some buildings have a long life which need long-lasting maintenance and a few of these maintenances are really distinctive [2]. As a result, LCA procedures implication to buildings may not be straightforward all time; it may create difficulties and uncertainties. In life cycle assessment of a building, several alternative designs are used to calculate the burden on environment and then an appropriate design is selected which can minimize the environmental load and evaluate the design's financial practicability. Furthermore, this environmental load is estimated in the schematic design phase and then green architectural practices are suggested to use in the design development phase. However, it is quite difficult to formulate a strategy of $\mathrm{CO}_{2}$ emissions where users have to directly insert the quantities of resources after the construction document phase in life cycle $\mathrm{CO}_{2}$ assessment [6]. In spite of carrying out a number of studies for two decades to quantify the potential environmental impacts due to construction and building sector, it reveals distinct comparison between the results and findings in terms of scope and methodology, design, data availability, quality and variation in climatic zones. Thus, sustainable buildings in different regions in the world are designed and built following local climatic conditions and the needs of the local population. Since none of these LCA methods can singly help to enable full assessment over the complete life cycle of a building, it is not possible to compare a building with the same one based on sustainability.

There are numerous studies related to LCA employed in analyzing energy consumption for sustainable building structures [5, 7-12]. Some researches specially focus on the choice of specific building materials like cement, concrete, steel, and wood [13-21]. Likewise, previous LCAs have applied to measure the associated environmental impacts due to subsystems of buildings, such as heating and cooling systems [22, 23], renewable energy techniques [24-27], and electrical and thermal systems [28, 29]. A survey of various cases expressed a linear relationship between total and operation energy demand and showed in case of low energy building construction, its life time energy demands reduces but embodied energy rises $[30,31]$. Also, Lower efficiency buildings were compared to multi-dwelling ones with respect to life time energy use $\left(\mathrm{GJ} / \mathrm{m}^{2}\right)$ and $\mathrm{CO}_{2}$ emissions $\left(\mathrm{kg} / \mathrm{m}^{2}\right)$ [32, 33]. Meanwhile, the comparative significance of life-cycle energy constituents of a building was found from the analysis where the embodied energy, the operational energy and disposal energy could vary from $2 \%$ to $51 \%, 46 \%$ to $97 \%$ and $1 \%$ to $3 \%$ respectively [34]. A number of studies have already discussed the results of LCA procedures where single buildings were used as case-studies [35-41]. Many previous studies have attempted to inaugurate a $\mathrm{CO}_{2}$ emission inventory and it has become very familiar in recent years [4245]. In last few years, researchers have found that operational phase of building accounts for the 
highest $\mathrm{CO}_{2}$ emissions (85\%) [46-50]. Several studies have suggested different technologies such as application of advanced energy-efficient equipment in buildings to minimize the carbon dioxide emissions in the operating stage of buildings [47, 50-55]. Moreover, numerous studies have dealt with impact of $\mathrm{CO}_{2}$ emissions from construction phase [46, 48, 51-53, 56-68]. In particular, most studies have concluded that use of low carbon materials and reuse of recycled materials would be effective approaches to reduce carbon dioxide emissions by up to $28 \%$ at the construction site $[13,58-62]$. In addition, application of external wall insulation, solar collectors and biomass based system could result in low energy consumption [63, 64]. However, it has been found from studies that using wood surplus, biomass energy, and other renewable energy resources can mitigate carbon emissions at a great extent $[65,66]$. In addition, one research has shown that it would be advantageous to replace highstrength reinforcing bars in different structural systems in case of reducing the emissions of carbon dioxide [67]. In spite of being the most complete tool for the environmental assessment of buildings, LCA requires profound amount of information along with experienced practitioner that is considered as the main difficulties in LCA [2]. Another difficulty in LCA application is the different results for identical cases can be obtained due to the application of different methods for impact calculation [68]. After observing these difficulties many researchers have simplified LCA methods in their studies [2, 69-71]. There are some other concepts for analyzing environmental impacts caused by a building which are quite similar to LCA such as life cycle energy analysis (LCEA) and life cycle cost analysis (LCCA) of buildings. These methodologies are found to be applied in the literature [71-74]. Life cycle energy analysis is used as a method to explore all energy (Embodied energy, Operating energy, and Demolition energy) available in a building's life cycle [31]. This paper depicts our assessment and comparison of the lifecycle impact of three conventional Bangladeshi buildings and we assessed the energy consumption and carbon dioxide emissions for various life phases of each building.

\subsection{Life cycle assessment (LCA)}

Life cycle assessment (LCA) is a process where it not only permits a record of materials and energy flows of a system but also evaluates the concomitant environmental influences. Typically, materials required for a product or service system whose manufacture, transportation, extraction and the system's construction, use, deconstruction, disposal and recycling are enumerated first. Afterwards, global or regional emergencies like global heating, ozone layer depletion, biodiversity losses and acidification are measured in terms of energy consumption, total material used and surplus materials disposed into the atmosphere throughout a system's life cycle. The International Organization for Standardization (ISO) has established four steps to conduct LCA analysis, that are- goal and scope definition; inventory analysis; life-cycle impact assessment (LCIA); and interpretation of results [76]. The goal and scope defines the functional unit, purposes, audiences, restraints of a system and quality standards for inventory data. The life cycle inventory analysis collects and organizes the information in terms of physical products and energy flow in various stages of the system's life cycle. The LCIA assigns these environmental impacts of diverse materials and energy flows into different environmental impact categories to quantify the consequences of possible environmental impacts. Finally, the interpretation of results from both second and third steps are needed to deal with the life cycle interpretation. Modern buildings are largescale projects where different kinds of materials are used and the limit of environmental criteria of these materials is possibly massive. This always creates an acute boundary limit to the application of LCA schemes in the building industry. Because of the less standard production method of the building materials, it is not possible to acquire compatible information regarding environmental impacts initiated by materialization, operation and demolition phases of construction materials. Environmental evaluation 
of the building industry seems quite a tough and laborious job due to these factors.

\subsection{The materialization stage}

Following to previous study, the materialization stage for life cycle analysis is the elaborate process and taking too much time. From a single raw material to whole formation, all process and all obstacles are comprehended in this stage. Here all the phases relates with raw materials extraction and manufacturing, transportation of the building material and entire construction process. There might be several stages and process in manufacturing of a single kind of buildings material and each of the stages which associated with energy usage contributed to carbon emission. If the energy and emission intensity for a unit product can be known, then the emission from the estimated quantity can be determined. It is hardly possible to encircle all the materials in this analysis because of the complexity and different qualities of their properties. That's why the materials and energy flow can be categorized for the selection process according to their usage [83]. According to construction phases, which materials, machinery and transportation is required in which stages can be reckoned and emission from those can also be enumerated easily. From the study of previous literature, many case studies use Ecoinvent which is a complete generic database and widely used to understand the environmental impact of construction material. Although it is recognized that the utilization of generic databases can offer assistance and reduce altogether the sum of information and complexity during product stage, representativeness of information cannot be guaranteed. It was observed in a few cases that when territorial LCI have not been available, information utilized from generic databases has been used to reflect territorial characteristics. Like Islam et al. [92] for their study utilize AusLCI database and European Ecoinvent database to Australian electricity and transportation. The carbon emission factor for different construction materials are enlisted in Table 1.
Table 1 Emission intensities of building materials

\begin{tabular}{lcc}
\hline Construction material & $\mathrm{CO}_{2}$ emission factor & Source \\
\hline $\begin{array}{l}\text { Steel (10\% recycled } \\
\text { content) }\end{array}$ & $2.21 \mathrm{~kg} \mathrm{co} / \mathrm{kg}$ & {$[94]$} \\
cement & $0.86 \mathrm{~kg} \mathrm{co} 2 / \mathrm{kg}$ & {$[93]$} \\
concrete & $0.2 \mathrm{~kg} \mathrm{co} 2 / \mathrm{kg}$ & {$[94]$} \\
Clay brick & $0.2 \mathrm{t} \mathrm{co} / \mathrm{t}$ & {$[83]$} \\
Float glass & $6.47 \mathrm{t} \mathrm{co}_{2} / \mathrm{m}^{3}$ & {$[93]$} \\
Polyvinyl chloride & $4.70 \mathrm{tco} 2 / \mathrm{t}$ & {$[83]$} \\
pipe & & \\
Wood products & $362.2 \mathrm{~kg} \mathrm{co} 2 / \mathrm{m}^{3}$ & {$[93]$} \\
Aluminum & $3.49-6.58 \mathrm{~kg} \mathrm{co} 2 / \mathrm{kg}$ & {$[78]$} \\
Ceramic/tile & $0.048-0.12 \mathrm{~kg} \mathrm{co} 2 / \mathrm{kg}$ & {$[78]$} \\
Architectural coating & $2.60 \mathrm{tco} 2 / \mathrm{t}$ & {$[83]$} \\
\hline
\end{tabular}

Total carbon emission at this stage can be calculated by adding the emission from material preparation, material transportation and construction of building. Emission from material preparation phase can be obtained by multiplying the quantity of each material with the emission factor of the material for its unit quantity production. Emission for transportation of material could be determined from the hauling distance and the types of fuel used by the locomotives. The common type of fuel used for truck in Bangladesh is diesel. A study was conducted in the transportation sector to assess the fuel consumption of the conventional trucks for carrying per ton of material. There are numerous variables that decide the quantity of diesel will be utilized by a truck per $\mathrm{km}$. For occasion, bigger motors will utilize more fuel than littler motors. Too, bigger vehicles, like 18-wheelers and expansive commercial trucks will utilize more fuel per kilometer than littler trucks and vans might utilize. On normal, in any case, bigger trucks can ordinarily utilize between 30 to 40 Liters of diesel for every hundred kilometers of running. Larger trucks that are utilized for commercial pulling, ordinarily utilize the biggest sum of fuel per kilometer. The carrier with weigh between 3 to 8 tons is the second-highest consumer of fuel. These vehicles utilize about 15 to 25 liters of diesel per 100 kilometers. 2-wheel drive pick-up 
vans regularly utilize between 8 to 14 liters per 100 kilometers. 12 to 15 liters of fuel is consumed by four wheel drive pick-up vans for per $100 \mathrm{~km}$. So the consumption of diesel for unit quantity of material transportation for per unit kilometer distance is $3.6 \times 10^{-2} \mathrm{~L} /(\mathrm{t} \mathrm{km}) . \mathrm{CO}_{2}$ emissions for per liter of diesel burned is $2.67 \mathrm{~kg}$ [77]. At the construction processes, the carbon emission is involved with the machinery used and the types of energy consumed at different phases of construction. Different kinds of construction machinery likes construction elevator, bar cutter, welder, concrete mixer, pump etc. are commonly used. Depends on the fuel required and fuel consumption by those machinery, the emission can be determined.

\subsection{Operation Phase}

The activities responsible for carbon emission at the operational phase are: the various types of energy utilized at daily use, maintenance works and any engineering renovation. Here, electricity, water, gas are the common types of energy consumed in the entire life span of a building. The operational electrical energy utilization of the building was calculated based on the examination of information on mechanical and electrical equipment design details as well as the expected utilization pattern of the building. The calculated electrical energy showed a good consistency with actual energy consumption. According to the purpose for which the building is used, energy consumption varies. For the commercial and educational building, electricity and water are the required energy, but in residential building gas is an inevitable source of energy. The energy demand closely related to the service life and standards of living. In the maintenance and renovation phase, the material and energy required can be calculated and the emission can be obtained as the same process at materialization stage.

\subsection{End of life phase}

The final stage of a building's life is called demolition and decommissioning. It is the common practise to use the majority portion of waste as landfilling. The emission from this disposal stage occurs mainly due to the energy consumption for demolition of building, waste transportation and recycling of waste. The wastes yielded from demolition of a building are predominantly masonry, concrete, steel, plastic, timber. Some of those can be recycled and reused, which causes the consumption of energy. The entire wastes can be categorized as structural wastes and finishing wastes [78]. Ferrous, non-ferrous metals and concrete fragments are included in structural wastes type and surplus cement mortar, broken mosaic, tiles, ceramics, paints and plastering materials are the example of finishing waste. Any waste consists of metal can be utilized in other construction site but the concrete and masonry waste can be recycled and only sector to use those is land reclamation. On the other side, the finishing waste which contains organic matter in a high portion cannot be recycled and reused. So the total carbon emission from this stage can be obtained by summing the emission from demolishment and waste disposal. Zhang [79] deduced a formula for the calculation of carbon emission from per unit area by considering the average hauling distance for the building waste $40 \mathrm{~km}$.

For demolishment, the carbon emission $\left(\mathrm{kg} / \mathrm{m}^{2}\right)=$ $0.06 \mathrm{X}+2.01$

For waste disposal, the carbon emission $\left(\mathrm{kg} / \mathrm{m}^{2}\right)=$ $0.54 \mathrm{X}+38.89$

$\mathrm{X}$ indicates the number of floors above the ground.

\subsection{Electricity generation scenario of Bangladesh}

At present, the electricity generation system of Bangladesh totally depends on the fossil fuel and a very little percentage comes from renewable energy sources. With the growing population and industrial sector, the demand of electricity is increasing alarmingly day by day. To meet the demand, new fossil fuel based power plants are being constructed. Greenhouse gas outflow is expanding alarmingly due to bulk power generation from fossil fuel such as coal, gas and oil with its constrained 
stock. In Bangladesh, about $8.12 \%$ of total installed capacity of electricity was produced using coal, $51.67 \%$ of electricity from gas, $27.5 \%$ using HFO, $5.92 \%$ of electricity came from HSD based power plants and rest amount from renewable source [84, 85]. In comparison among various fossil fuels, coal generates noticeable amount of detrimental greenhouse gasses particularly carbon di oxide, sulfur di oxide, nitrite oxide. In Bangladesh, more than $50 \%$ of total generation of electricity is produced from the power plant where natural gas is used as fuel. Power production based on ordinary Liquefied Normal Gas (LNG) radiates 38\% less GHG in comparison to dark coal [86]. The generation system based on using hydrocarbons such as heavy fuel oil, diesel, gasoline and liquefied petroleum is experiencing troubles because those are relatively costly and emit carbon to atmosphere. An investigation reports that coal produces $0.87 \mathrm{~kg}$, natural gas produces $0.42 \mathrm{~kg}$ and diesel produces $0.63 \mathrm{~kg}$ of $\mathrm{CO}_{2}$ for unit $\mathrm{kWh}$ of electricity production in the power generation of New Zealand [87]. A study on Life Cycle Assessment (LCA) of greenhouse gas emission observed in Macau city, China exhibits that electricity production from natural gas, heavy oil \& solid waste burning causes $0.42 \mathrm{~kg}, 0.7 \mathrm{~kg}$ and $0.95 \mathrm{~kg}$ of $\mathrm{CO}_{2}$ emission per $\mathrm{kWh}$, respectively [88]. An investigation conducted on the power generation systems of Bangladesh where fossil fuel is used by utilizing HOMER (Hybrid Optimization of Multiple Energy Resources) software shows that coal based power plants emits $0.90 \mathrm{~kg}$, diesel based power plants emits $0.76 \mathrm{~kg}$ and natural gas based power plants emits $0.566 \mathrm{~kg}$ of $\mathrm{CO}_{2}$ for generating per $\mathrm{kWh}$ of electricity and according to them approximate outflow of carbon from those power plants is 0.64 $\mathrm{kg} / \mathrm{kWh}$ [89]. Hasan andChongbo [90] expressed the scenario of future carbon emission by examining the carbon emission data in electricity generation sector from 1979 to 2018 applying the logarithmic mean divisia index (LMDI) method and commented that the conceivable sum of fossil fuelrelated carbon outflows from the power sector of Bangladesh were $36.98 \mathrm{Mt}$ in 2019 and approximately $39 \mathrm{Mt}$ in 2021 . In this study $0.64 \mathrm{~kg}$ of carbon was considered emitted for per unit electricity generation [89].

\subsection{Functional unit}

In LCA Functional unit is to be chosen to present and evaluate the environmental impact [82]. As per ISO 14040 , the reference unit is used to quantify the system performance in LCA techniques [91]. Through the functional unit the input-output materials can be linked with energy flows [92]. Several types of functional unit are used in LCA of buildings, like per $\mathrm{m}^{2}$ of usable floor area, per number of rooms, per $\mathrm{m}^{2}$ of usable/living floor area per year ( $\mathrm{m}^{2} /$ year), per number of dwellings, per $\mathrm{m}^{3}$ of gross volume of building etc. In this study we chose per square meter of usable floor area as a functional unit.

\section{Methodology}

Basically three types of methodologies for life cycle assessment are practiced. Those are: process based LCA, input- output LCA and hybrid LCA [82]. In this study we adopted the first method, where the user mark out the forms related with life-cycle phases of a product and implicates the inputs and outputs with each process. Eventually the overall environmental load can be calculated. The process based LCA is based on scientifically analyzing the actual process and the ISO 14040 Standards [76] are primarily related with the process-based methodology. This type of assessment is very specific and flexible but requires huge quantities of data. As the assessment of carbon emission from a building is very extensive job, because lots of activities associated with the construction of a building. For accurate assessment of carbon emission, all the phases are needed to be examined as how much the phase contribute to the carbon emission. Here, to realize a full thought of the complete building life-cycle and guarantee the exactness of consequent calculations, the life-cycle was separated into three stages which are previously discussed from the viewpoint of material and energy flow: (1) the materialization stage, consolidating raw materials production and their transportation and on-site development; (2) the 
usage stage, consolidating every day utilize, schedule maintenance, and building renovation; and (3) the end of life stage, consolidating building annihilation, waste transportation, and reusing. All the phases considered here are depicted in Fig. 1.

\subsection{Case study}

The three selected typical buildings-Residential (five storied), Educational (three storied) and Commercial (three storied) - are situated in three different region of Bangladesh. These buildings have 50 years of service lifetime. Whereas in residential building electricity is mainly consumed by fans, lights, air conditioner, heater, washing machine, computer or laptops, in educational building the computer systems, lighting, cooling or heating systems and heavy or small machineries consumes the electricity. In case of commercial building, lighting, cooling, ventilation system, escalator, computers are the main sources that consume electricity for a long period than residential and education building. The main construction materials considered in this study are: Cement mortar, Steel, Reinforced Concrete Cement (RCC) framework, brick masonry, Glass, Timber, Aluminum, Ceramic products. The basic information about the buildings are shown in Table 2 and pictorial views of the three buildings are presented in Fig. 2, Fig. 3, and Fig. 4.

\section{Results and discussion}

\subsection{Emission at materialization stage}

The emission for the three different types building was enumerated according the adopted method. The extent of required raw materials was estimated from quantitative assessment and emissions for material preparation were described in Table 3. The calculated emissions only for the primary materials were $354.21 \mathrm{t}$ for residential building, 1573.45t for educational building and $414.11 \mathrm{t}$ for commercial building. The emission for other materials preparation were estimated as $1 / 3$ of the primary materials [81]. The emission by the transportation of the raw material was calculated by estimating the
Table 2 Information of the studied buildings

\begin{tabular}{lll}
\hline Building type & $\begin{array}{l}\text { Gross Floor } \\
\text { Area }\left(\mathrm{m}^{2}\right)\end{array}$ & Location \\
\hline Residential building & 824 & $\begin{array}{l}\text { Mymensingh, } \\
\text { Bangladesh }\end{array}$ \\
Educational building & 4760 & $\begin{array}{l}\text { Dhaka, } \\
\text { Bangladesh }\end{array}$ \\
Commercial building & 1755 & $\begin{array}{l}\text { Dhaka, } \\
\text { Bangladesh }\end{array}$ \\
\hline
\end{tabular}

hauling distance. Usually truck was used for the transshipment of all the materials. Depends on the availability, the materials were collected from different locations. Some locally available materials were used and some were shifted from far distance. The emission scenario was shown in Table 4 and the emission were $6.91 \mathrm{t}$ for residential building, 36.99t for educational building and 10.29t for commercial building. Carbon emission from construction phase was enumerated based on the power and fuel consumption by the construction machinery. Due to the availability of workman at low cost and as a developing country, the utility of machinery in construction industry is not practiced at a wide scale. The commonly used machinery are bar cutter, concrete vibrator, centrifugal pump, Direct current welder, concrete mixer. The data of emission rate of those machinery has been collected from site survey and available literature [83] and the emission status has been described in Table 5. Therefore, the total emission at materialization stage were $489.94 \mathrm{t}$ for residential building, 2191.75t for educational building and 574.59t for commercial building.

\subsection{Emission at operation and demolition phase}

The impact of operation phase normally assessed based on the energy usage, the maintenance and renovation works. Electrical energy required for lighting, cooling, ventilation, household machinery, elevators, computers, running different machinery. Gas has been also used for cooking purpose in residential building, which produces $2.7 \mathrm{~kg} \mathrm{CO}_{2}$ for burning unit $\mathrm{kg}[80]$. 


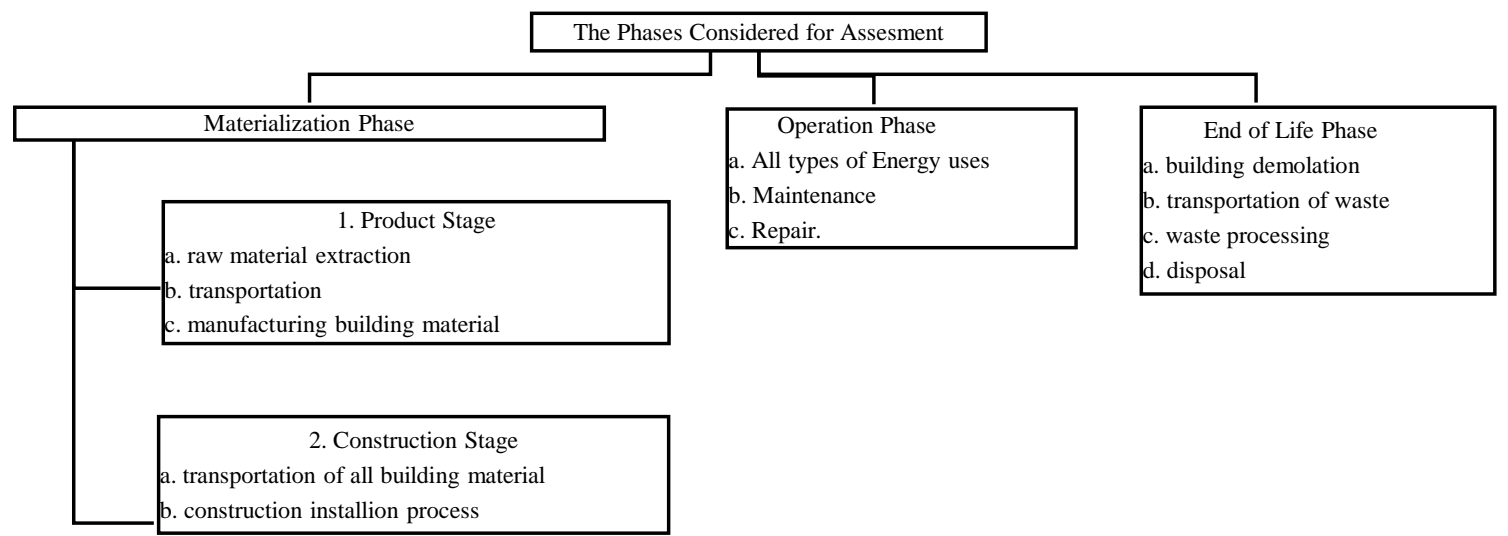

Fig. 1. Different phases considered for assessment

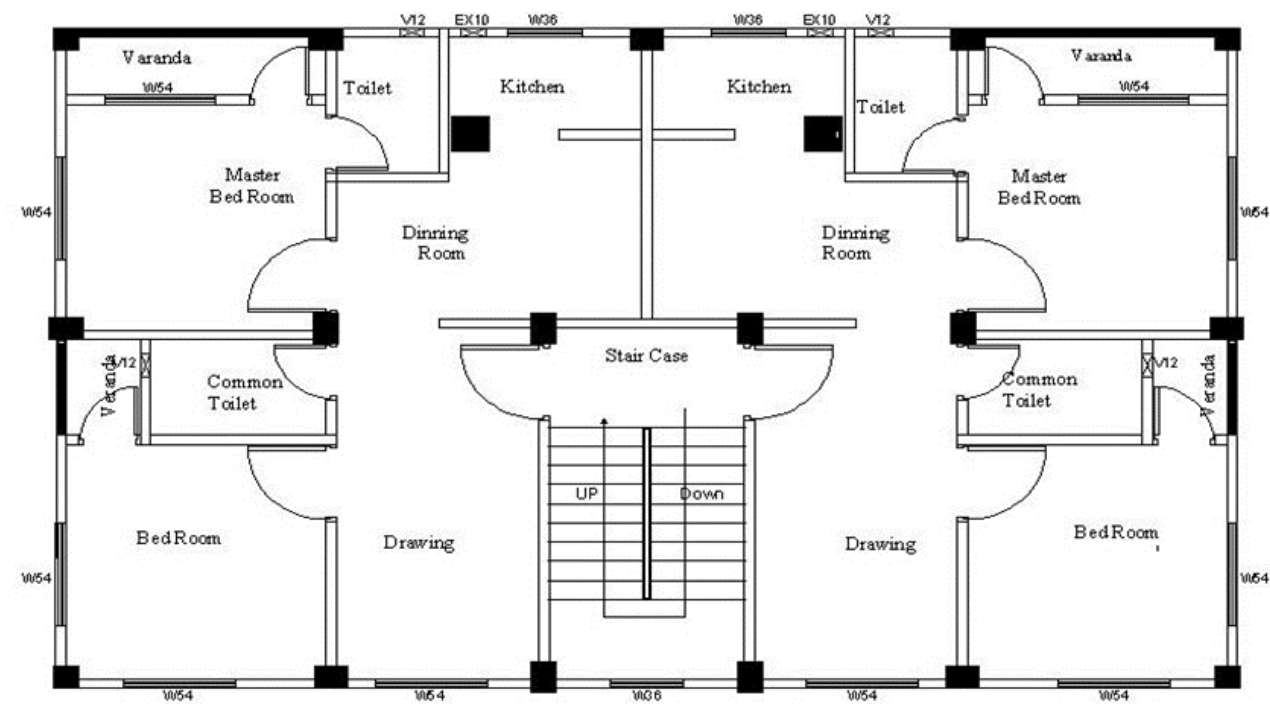

Fig. 2. Residential building plan

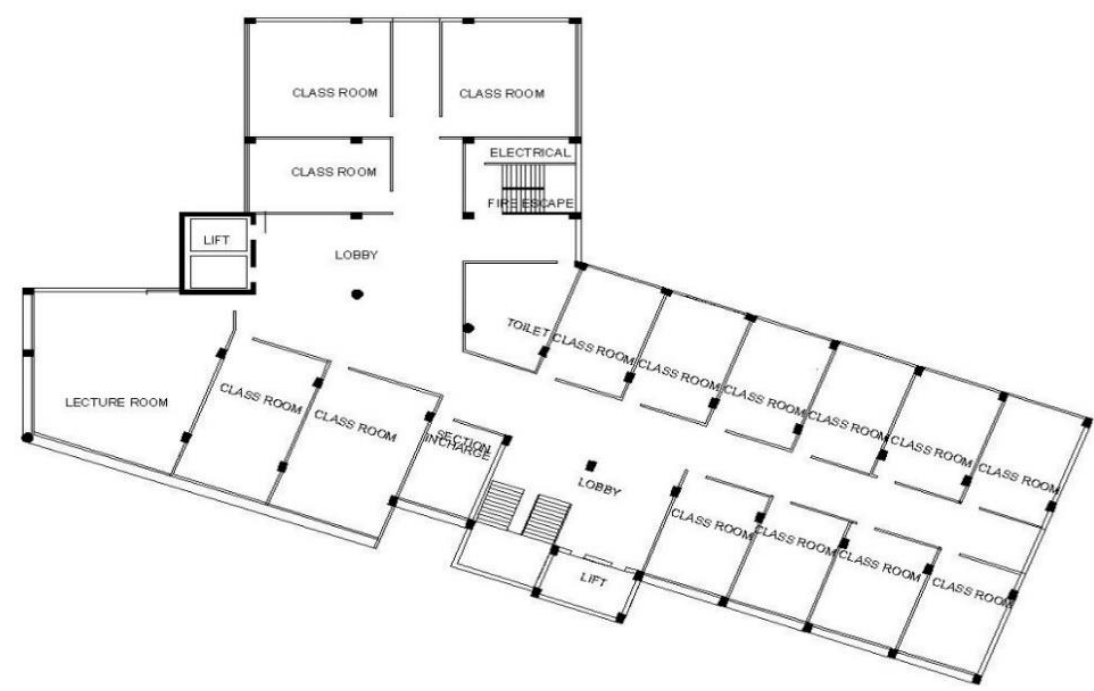

Fig. 3. Educational building plan 


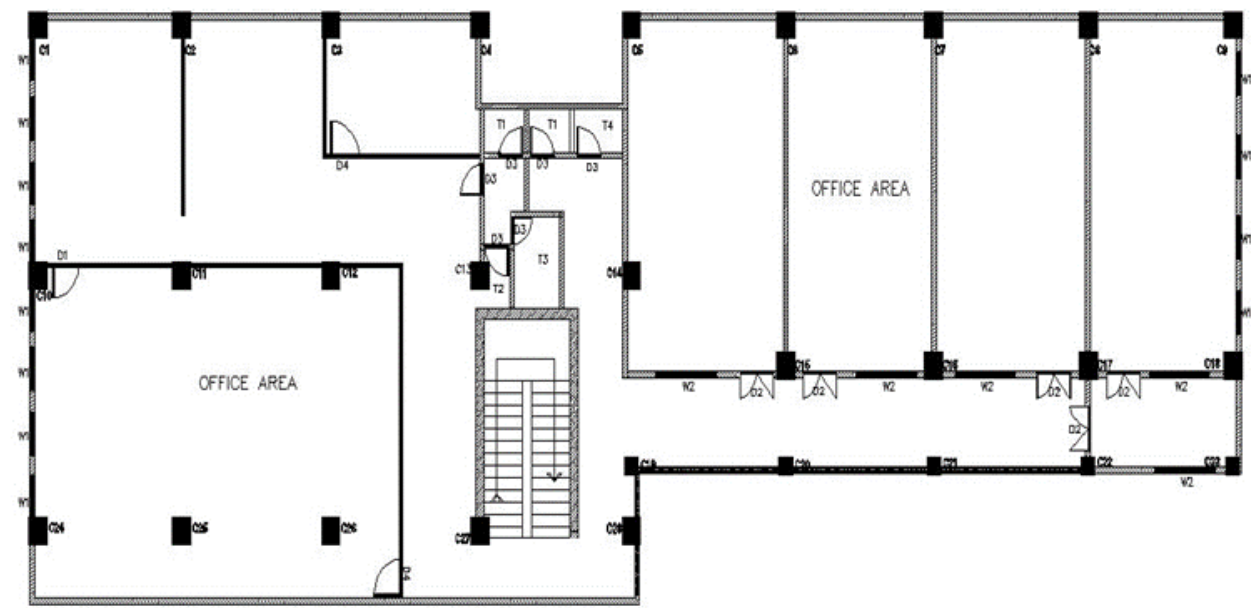

Fig. 4. Commercial building plan

Table 3. Carbon emission for material preparation.

\begin{tabular}{|c|c|c|c|}
\hline S. No & Name of item & Quantity & Carbon Emission ( ton) \\
\hline \multicolumn{4}{|c|}{ Residential Building } \\
\hline 1 & Concrete & 984 ton & 196.8 \\
\hline 2 & Cement & $23600 \mathrm{~kg}$ & 20.3 \\
\hline 3 & Steel & 49 ton & 108.3 \\
\hline 4 & Clay Brick & $24.7 \mathrm{~m}^{3}$ & 9.88 \\
\hline 5 & Ceramic products & 55 ton & 4.62 \\
\hline 6 & Wood products & $19 \mathrm{~m}^{3}$ & 6.88 \\
\hline 7 & Architectural coating & 0.603 ton & 1.57 \\
\hline 8 & Aluminum & $264 \mathrm{~kg}$ & 1.33 \\
\hline 9 & Glass & $0.7 \mathrm{~m}^{3}$ & 4.53 \\
\hline 10 & Others & & 118.07 \\
\hline \multicolumn{3}{|c|}{ Total } & 472.28 \\
\hline \multicolumn{4}{|c|}{ Educational Building } \\
\hline 1 & Concrete & 4320 ton & 864 \\
\hline 2 & Cement & $126121 \mathrm{~kg}$ & 108.6 \\
\hline 3 & Steel & 222 ton & 490.62 \\
\hline 4 & Clay Brick & $132 \mathrm{~m}^{3}$ & 52.8 \\
\hline 5 & Ceramic products & 178 ton & 14.95 \\
\hline 6 & Wood products & $47 \mathrm{~m}^{3}$ & 17.02 \\
\hline 7 & Architectural coating & 6.3 ton & 16.38 \\
\hline 8 & Aluminum & $364 \mathrm{~kg}$ & 1.83 \\
\hline 9 & Glass & $1.12 \mathrm{~m}^{3}$ & 7.25 \\
\hline 10 & Others & & 524.48 \\
\hline \multicolumn{3}{|c|}{ Total } & 2097.93 \\
\hline \multicolumn{4}{|c|}{ Commercial Building } \\
\hline 1 & Concrete & 1056 ton & 211.2 \\
\hline 2 & Cement & $42000 \mathrm{~kg}$ & 36.12 \\
\hline 3 & Steel & 62 ton & 137.02 \\
\hline 4 & Clay Brick & $36 \mathrm{~m}^{3}$ & 14.4 \\
\hline 5 & Ceramic products & 43 ton & 3.61 \\
\hline 6 & Wood products & $18 \mathrm{~m}^{3}$ & 6.52 \\
\hline 7 & Architectural coating & 0.8 ton & 2.08 \\
\hline 8 & Aluminum & $114 \mathrm{~kg}$ & 0.57 \\
\hline 9 & Glass & $0.4 \mathrm{~m}^{3}$ & 2.59 \\
\hline 10 & Others & & 138.04 \\
\hline \multicolumn{3}{|c|}{ Total } & 552.15 \\
\hline
\end{tabular}


Table 4. Calculation of emission for transportation

\begin{tabular}{|c|c|c|c|c|c|c|c|c|c|c|c|c|}
\hline \multirow[b]{2}{*}{ Materials } & \multicolumn{4}{|c|}{ Residential Building } & \multicolumn{4}{|c|}{ Educational Building } & \multicolumn{4}{|c|}{ Commercial Building } \\
\hline & $\begin{array}{c}\text { Distance } \\
(\mathrm{km})\end{array}$ & Route & $\begin{array}{l}\text { Weight } \\
(\mathrm{t})\end{array}$ & $\begin{array}{c}\mathrm{CO}_{2} \\
\text { emissions } \\
(\mathrm{t})\end{array}$ & $\begin{array}{c}\text { Distance } \\
(\mathrm{km})\end{array}$ & Route & $\begin{array}{l}\text { Weight } \\
\text { (t) }\end{array}$ & $\begin{array}{c}\mathrm{CO}_{2} \\
\text { emissions } \\
(\mathrm{t})\end{array}$ & $\begin{array}{c}\text { Distance } \\
(\mathrm{km})\end{array}$ & Route & $\begin{array}{l}\text { Weight } \\
\text { (t) }\end{array}$ & $\begin{array}{c}\mathrm{CO}_{2} \\
\text { emissions } \\
(\mathrm{t})\end{array}$ \\
\hline steel & 360 & $\begin{array}{l}\text { Chittagong } \\
\text { to work } \\
\text { site }\end{array}$ & 49 & 1.7 & 246 & $\begin{array}{l}\text { Chittagong } \\
\text { to work } \\
\text { site }\end{array}$ & 222 & 5.25 & 241 & $\begin{array}{l}\text { Chittagong } \\
\text { to work } \\
\text { site }\end{array}$ & 62 & 1.44 \\
\hline cement & 179 & $\begin{array}{l}\text { Sylhet to } \\
\text { work site }\end{array}$ & 122.1 & 2.1 & 262 & $\begin{array}{l}\text { Sylhet to } \\
\text { work site }\end{array}$ & 558.4 & 14.06 & 260 & $\begin{array}{l}\text { Sylhet to } \\
\text { work site }\end{array}$ & 147.67 & 3.70 \\
\hline $\begin{array}{l}\text { Clay } \\
\text { brick }\end{array}$ & 15 & $\begin{array}{l}\text { Factory } \\
\text { to work } \\
\text { site }\end{array}$ & 459.4 & 0.65 & 25 & $\begin{array}{l}\text { Factory } \\
\text { to work } \\
\text { site }\end{array}$ & 2064 & 4.96 & 28 & $\begin{array}{l}\text { Factory } \\
\text { to work } \\
\text { site }\end{array}$ & 512 & 1.38 \\
\hline sand & 18 & $\begin{array}{l}\text { Locality } \\
\text { to work } \\
\text { site }\end{array}$ & 424.3 & 0.73 & 30 & $\begin{array}{l}\text { Locality } \\
\text { to work } \\
\text { site }\end{array}$ & 1202.7 & 3.47 & 32 & $\begin{array}{l}\text { Locality } \\
\text { to work } \\
\text { site }\end{array}$ & 391.2 & 1.20 \\
\hline Others & & & & 1.73 & & & & 9.25 & & & & 2.57 \\
\hline Total & & & & 6.91 & & & & 36.99 & & & & 10.29 \\
\hline
\end{tabular}

Table 5. Emission at construction phase

\begin{tabular}{|c|c|c|c|c|c|c|c|}
\hline \multirow{2}{*}{$\begin{array}{l}\text { Construction } \\
\text { Machinery }\end{array}$} & \multirow{2}{*}{$\begin{array}{l}\text { Emission } \\
\text { Factor } \\
\left(\mathrm{KgCO}_{2} /\right. \\
\text { Hour })\end{array}$} & \multicolumn{2}{|c|}{ Residential Building } & \multicolumn{2}{|c|}{ Educational Building } & \multicolumn{2}{|c|}{ Commercial Building } \\
\hline & & $\begin{array}{l}\text { Working } \\
\text { Hours }\end{array}$ & $\begin{array}{l}\mathrm{CO}_{2} \\
\text { Emissions, } \\
\mathrm{Kg}\end{array}$ & $\begin{array}{l}\text { Working } \\
\text { Hours }\end{array}$ & $\begin{array}{l}\mathrm{CO}_{2} \\
\text { Emissions, } \\
\mathrm{Kg}\end{array}$ & $\begin{array}{l}\text { Working } \\
\text { Hours }\end{array}$ & $\begin{array}{l}\mathrm{CO}_{2} \\
\text { Emissions, } \\
\mathrm{Kg}\end{array}$ \\
\hline Earth Excavator & 32.04 & 28 & 897.12 & 228 & 7305.12 & 42 & 1345.68 \\
\hline $\begin{array}{l}\text { Concrete } \\
\text { Vibrator }\end{array}$ & 1.1 & 518 & 569.8 & 2275 & 2502.5 & 556 & 611.6 \\
\hline Bar Cutter & 3.89 & 67 & 260.63 & 302 & 1174.78 & 85 & 330.65 \\
\hline $\begin{array}{l}\text { Centrifugal } \\
\text { Pump }\end{array}$ & 22 & 380 & 8360 & 1950 & 42900 & 410 & 9020 \\
\hline $\begin{array}{l}\text { Direct Current } \\
\text { Welder }\end{array}$ & 11 & 51 & 561 & 232 & 2552 & 63 & 693 \\
\hline $\begin{array}{l}\text { Drum Concrete } \\
\text { Mixer }\end{array}$ & 2.96 & 33 & 97.68 & 132 & 390.72 & 52 & 153.92 \\
\hline Total & & & 10746.23 & & 56825.12 & & 12154.85 \\
\hline
\end{tabular}

As those buildings were newly built, enough data for maintenance and renovation works were not available. Hence, $2 \%$ of emission at materialization stage was considered as the emission for maintenance [82] which is $9.8 \mathrm{t}$ for residential building, $43.84 \mathrm{t}$ for educational building and $11.5 \mathrm{t}$ for commercial building. Hence, for 50 years life span, total emission at operation phase were residential building: 1004t, educational building: 6036t and commercial building: 3053t and the details shown in Table 6. The emission at demolition and disposal phase was calculated according to the formula proposed by Zhang [79] and the emission values shown in Table 7.

\subsection{Carbon emission status}

The entire life cycle analysis of three different purpose serving buildings presented the scenario of carbon emission. The total life cycle carbon discharge contributed by residential building, Educational Building and Commercial Building were $1856.9 \mathrm{~kg} / \mathrm{m}^{2}, 1773.5 \mathrm{~kg} / \mathrm{m}^{2}$ and $2109.7 \mathrm{~kg} / \mathrm{m}^{2}$ respectively by considering their life span 50 years. 
Table 6. Emission at operational phase

\begin{tabular}{lllllll}
\hline \multirow{2}{*}{$\begin{array}{l}\text { Types of } \\
\text { energy }\end{array}$} & \multicolumn{2}{c}{ Residential building } & \multicolumn{2}{c}{ Educational building } & \multicolumn{2}{c}{ Commercial building } \\
\cline { 2 - 7 } & $\begin{array}{l}\text { Annual } \\
\text { consumption }\end{array}$ & $\begin{array}{l}\text { Annual } \\
\text { Emission }\end{array}$ & $\begin{array}{l}\text { Annual } \\
\text { consumption }\end{array}$ & $\begin{array}{l}\text { Annual } \\
\text { Emission }\end{array}$ & $\begin{array}{l}\text { Annual } \\
\text { consumption }\end{array}$ & $\begin{array}{l}\text { Annual } \\
\text { Emission }\end{array}$ \\
\hline Electricity & $24720 \mathrm{kwh}$ & $15821 \mathrm{~kg}$ & $187250 \mathrm{kwh}$ & $119840 \mathrm{~kg}$ & $95050 \mathrm{kwh}$ & $60832 \mathrm{~kg}$ \\
Gas & $1500 \mathrm{~kg}$ & $4050 \mathrm{~kg}$ & & & & \\
\hline
\end{tabular}

Table 7. Emission for demolition and waste disposal.

\begin{tabular}{lccc}
\hline Process & $\begin{array}{c}\text { Residential Building } \\
\left(\mathrm{Kg} / \mathrm{m}^{2}\right)\end{array}$ & $\begin{array}{c}\text { Educational Building } \\
\left(\mathrm{Kg} / \mathrm{m}^{2}\right)\end{array}$ & $\begin{array}{c}\text { Commercial Building } \\
\left(\mathrm{Kg} / \mathrm{m}^{2}\right)\end{array}$ \\
\hline Demolishment & 2.31 & 2.37 & 2.19 \\
Waste Disposal & 41.59 & 42.13 & 40.51 \\
\hline
\end{tabular}

From the assessment of material preparation phase as demonstrated in Fig. 5 , it is clear that concrete and steel are the main contributor of carbon where the emission by concrete are $41.67 \%, 41.18 \%$, $38.25 \%$ and emission by steel are $22.93 \%, 23.39 \%$, $24.82 \%$ of the total emission at material manufacturing phase for residential building, educational building and commercial building respectively. The materialization stage is accountable for $32.04 \%, 26 \%$ and $15.5 \%$ of total emission where concrete emits $12.86 \%, 10.23 \%$, $5.7 \%$ of total emission and steel emits $7.1 \%, 5.8 \%$, $3.7 \%$ of total emission for residential building, educational building and commercial building respectively. The transportation phase contributed $0.45 \%, 0.44 \%, 0.28 \%$ and construction phase was responsible for $0.70 \%, 0.67 \%$, and $0.33 \%$ of total life time emission for residential building, educational building and commercial building respectively. Among the three phases of life cycle assessment, the operational stage is mainly liable for maximum emission. As shown in Fig. 6, the emission of operational phase are $65.6 \%, 71.5 \%$, $82.5 \%$ of the whole life emission for residential building, educational building and commercial building respectively. This high value of emission at operational phase is due to higher consumption of electricity over the life time. As the commercial building operates for 18 hours in a day, a huge number of lighting, cooling, ventilation system, escalator, computers are kept running for long time and consumes energy comparatively higher than residential building, educational building. The air conditioning system is mostly responsible for more than 30 percent consumption of total electricity. The materialization and operation stages together contributed more than $97 \%$ emission. The emission per unit usable floor are actually depends on the purpose for which the building has been constructed, weather condition and the construction material. With almost same construction material and weather condition, within the three different buildings commercial building emits highest quantity of carbon. The emission from commercial building is $13.6 \%$ more than residential building and $19 \%$ more than educational building. Also the floor area, material used per unit volume of building and interior room arrangements are significant parameters controlling emission. For instance, the emission of residential building at materialization stage is more than educational and commercial building.

\section{Conclusions}

In this study, all the possible phases of building life associated with carbon emission have been analyzed and total emission has been estimated based on each activity. It was also obvious that the operation phase was the main contributor due to the huge numbers of electrical appliances and has the environmental adverse effect. 


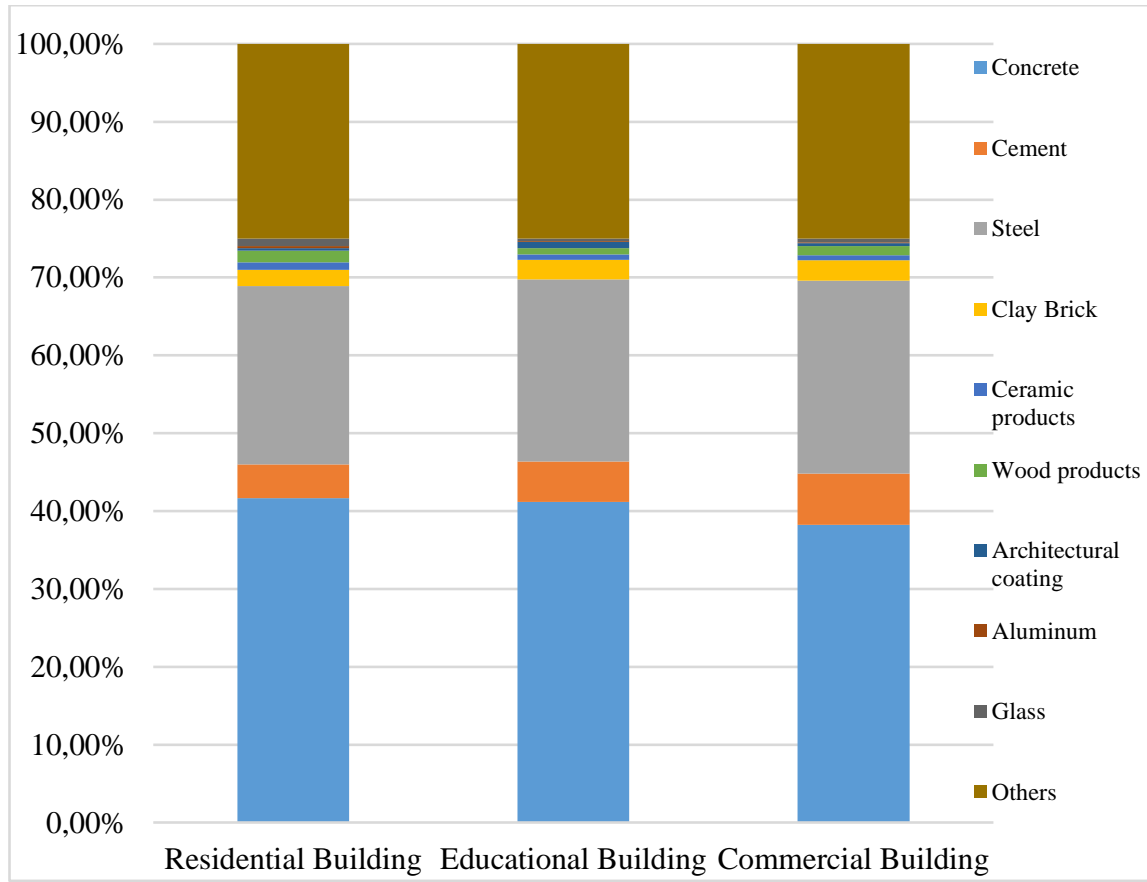

Fig. 5. Emission percentage contributed by material at manufacturing phase

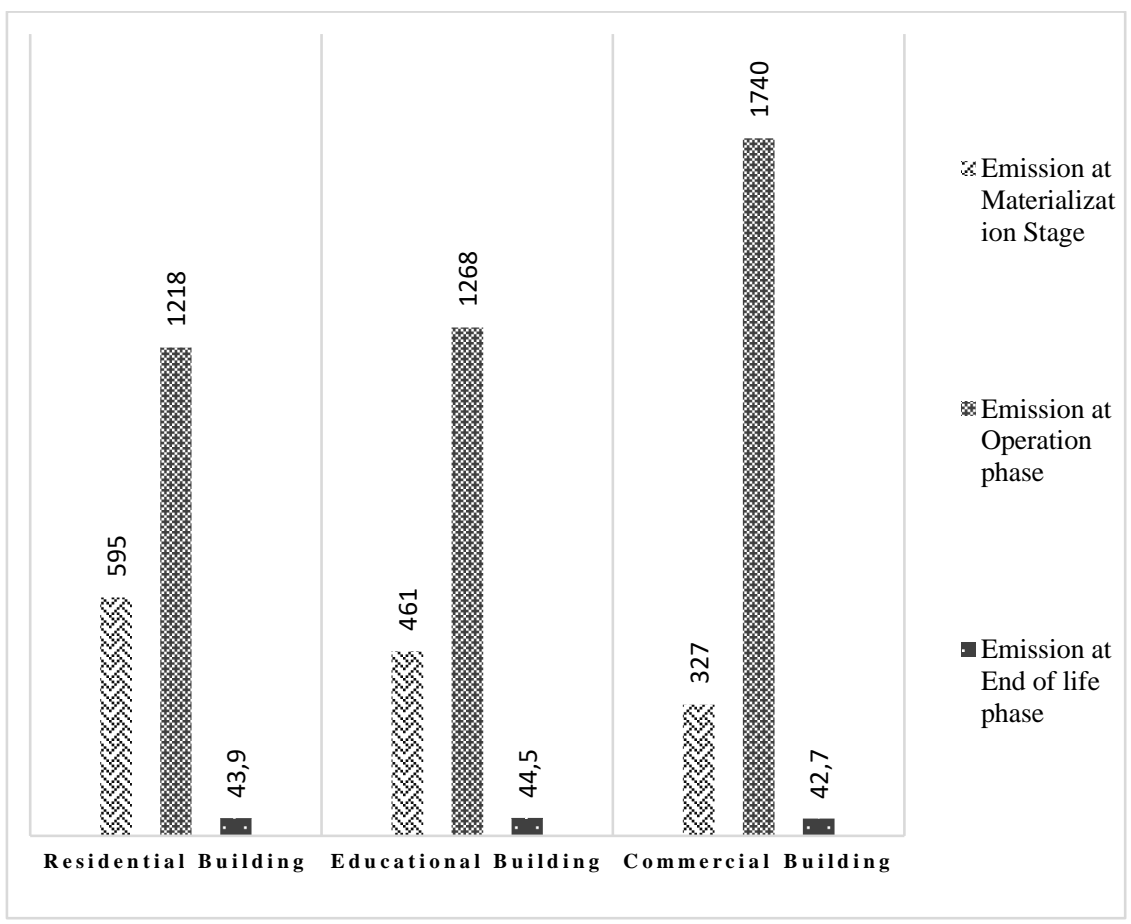

Fig. 6. Carbon emission $\left(\mathrm{kg} / \mathrm{m}^{2}\right)$ at different phase 
To reduce this emission quantity, the design of buildings and energy source should be selected in a wise way. Some effective techniques have to be adopted in such way that there will be least material, operational energy requirements. As a topographical region, majority time in a year there high temperature prevails and cooling demand is comparatively higher. So the engineers and architects ought to research the technique to construct energy efficient buildings to maintain comfortable room temperature, well ventilation and proper lighting condition. The types of fuel used for electricity production in Bangladesh are highly responsible for extensive quantity of carbon production. The present scenario exhibits that a marginal amount of electricity is obtained from renewable source and fossil-fuel is broadly used for electricity production. This sector need to be comprehensively emphasized to increase the production using renewable energy source which ultimately reduce emission at operation phase of any building which uses electrical energy. It is troublesome to conduct a complete and appropriate life cycle assessment of a building, as lots of data is associated with this process and unavailability of some data. Nevertheless, this study tries to figure the approximate emission of these three buildings.

\section{Declaration of conflicting interests}

The author(s) declared no potential conflicts of interest with respect to the research, authorship, and/or publication of this article.

\section{References}

[1] Erlandsson M, Borg M (2003) Generic LCAmethodology applicable for buildings, constructions and operation services-today practice and development needs. Building and Environment, 38:919-938.

[2] Bribián IZ, Usón AA, Scarpellini S (2009) Life cycle assessment in buildings: state of the art and simplified LCA methodology as a complement for building certification. Building and Environment, 44(12):2510-2520.

[3] Tae S, Shin S (2009) Current work \& future trends for sustainable buildings in South Korea.
Renewable \& Sustainable Energy Review, 13(8):1910-1921.

[4] Sandanayake M, Zhang G, Setunge S (2018) A comparative method of air emission impact assessment for building construction activities. Environmental Impact Assessment Review, 68:19.

[5] Han MY, Chen GQ, Shao L, Li JS, Alsaedi A, Ahmad B, Guo S, Jiang MM, Ji X (2013) Embodied energy consumption of building construction engineering: Case study in E-town, Beijing. Energy and Buildings, 64:62-72.

[6] Baek C, Parkb S H, Suzuki M, Lee SH (2013) Life cycle carbon dioxide assessment tool for buildings in the schematic design phase. Energy and Buildings, 61:275-287.

[7] Olawumi TO, Chan DWM, Chan APC, Wong JKW (2020) Development of a building sustainability assessment method (BSAM) for developing countries in sub-Saharan Africa. Journal of Cleaner Production, 263:121514.

[8] Blengini GA, Carlo Di T (2010) Energy-saving policies and low-energy residential buildings: an LCA case study to support decision makers in Piedmont (Italy). The International Journal of Life Cycle Assessment, 15(7):652-65.

[9] Adalberth K, Almgren A, Petersen EH (2001) Life cycle assessment of four multi-family buildings. International Journal of Low Energy and Sustainable Buildings, 2:1-21.

[10] Guan J, Zhang Z, Chu C (2016) Quantification of building embodied energy in China using an inputoutput-based hybrid LCA model. Energy and Buildings, 110:443-52.

[11] Asdrubali F, Baldassarri C, Fthenakis V (2013) Life cycle analysis in the construction sector: Guiding the optimization of conventional Italian buildings. Energy and Buildings, 64:73-89.

[12] Hajare A, Elwakil E (2020) Integration of life cycle cost analysis and energy simulation for building energy-efficient strategies assessment. Sustainable Cities and Society, 61:102293.

[13] Park J, Tae S, Kim T (2012) Life cycle CO2 assessment of concrete by compressive strength on construction site in Korea. Renewable and Sustainable Energy Reviews, 16(5):2940-2946.

[14] Wu P, Xia B, Zhao X (2014) The importance of use and end-of-life phases to the life cycle greenhouse gas (GHG) emissions of concrete - a review. Renewable and Sustainable Energy Reviews, 37:360-69. 
[15] Knoeri C, Mengual Sanye E, Althaus HJ (2013) Comparative LCA of recycled and conventional concrete for structural applications. The International Journal of Life Cycle Assessment, 18(5):909-918.

[16] Cagiao J, Gómez B, Doménech JL, Mainar SG (2011) Calculation of the corporate carbon footprint of the cement industry by the application of MC3 methodology. Ecological Indicators, 11(6):1526-1540.

[17] Peyroteo A, Silva M, Jalali S. Life cycle assessment of steel and reinforced concrete structures: a new analysis tool. In: Bragança L et al. (ed) Portugal SB07-Sustainable Construction, Materials and Practices, IOS Press, 2007, pp 397-402.

[18] Rivela B, Hospido A, Moreira T, Feijoo G (2006) Life cycle inventory of particleboard: a case study in the wood sector. The International Journal of Life Cycle Assessment, 11(2):106-13.

[19] Nebell B, Zimmer B, Wegener G (2006) Life cycle assessment of wood floor coverings-a representative study for the German flooring industry. The International Journal of Life Cycle Assessment, 11(3):172-82.

[20] Thormark C (2002) A low energy building in a life cycle - its embodied energy, energy need for operation and recycling potential. Building and Environment, 37:429-435.

[21] Thormark C (2006) The effect of material choice on the total energy need and recycling potential of a building. Building and Environment, 41:10191026.

[22] Prek M (2004) Environmental impact and life cycle assessment of heating and air conditioning systems-a simplified case study. Energy and Buildings, 36(10):1021-1027.

[23] Ghose A, McLaren SJ, Dowdell D (2020) Upgrading New Zealand's existing office buildings - An assessment of life cycle impacts and its influence on 2050 climate change mitigation target. Sustainable Cities and Society, 57:102134.

[24] Cucchiella F, D'Adamo I (2012) Estimation of the energetic and environmental impacts of a roofmounted building-integrated photovoltaic systems. Renewable and Sustainable Energy Reviews, 16(7):5245-59.

[25] Bougiatioti F, Michael A (2015) The architectural integration of active solar systems. Building applications in the Eastern Mediterranean region. Renewable and Sustainable Energy Reviews, 47:966-82.
[26] MBIE. New Zealand's energy outlook- energy insight. Wellington: New Zealand Government. 2012. https://www.mbie.govt.nz/building-andenergy/energy-and-naturalresources/energystatistics-and-modelling/energy-modelling/newzealands-energyoutlook/new-zealands-energyoutlook-electricity-insight/.

[27] Smith N. Toward $100 \%$ renewable electricity. Accessed $30 \quad$ June 2019, https://www.greens.org.nz/sites/default/files/Towa rd\%20100\%25.pdf.

[28] Osman A, Ries R (2007) Life cycle assessment of electrical and thermal energy systems for commercial buildings. The International Journal of Life Cycle Assessment, 12(5):308-316.

[29] Lamnatou C, Mondol JD, Chemisana D, Maurer C (2015) Modelling and simulation of buildingintegrated solar thermal systems: behaviour of the coupled building/ system configuration. Renewable and Sustainable Energy Reviews, 48:178-191.

[30] Sartori I, Hestnes AG (2007) Energy use in the life cycle of conventional and low-energy buildings: a review article. Energy and Buildings, 39:249-257.

[31] Ramesh T, Prakash R, Shukla KK (2010) Life cycle energy analysis of buildings: an overview. Energy and Buildings, 42(10):1592-1600.

[32] Nassen J, Holmberg J, Wadeskog A, M Nyman (2007) Direct and indirect energy use and carbon emissions in the production phase of buildings: an input-output analysis. Energy, 32:1593-1602.

[33] Verbeeck G, Hens H (2010) Life cycle inventory of buildings: a contribution analysis. Building and Environment, 45:964-967.

[34] Optis M, Wild P (2010) Inadequate documentation in published life cycle energy reports on buildings. International Journal Life Cycle Assessment, 15:644-651.

[35] Asif M, Muneer T, Kelley R (2007) Life cycle assessment: a case study of a dwelling home in Scotland. Building and Environment, 42:13911394.

[36] Monahan J, Powell JC (2011) An embodied carbon and energy analysis of modern methods of construction in housing: a case study using a lifecycle assessment framework. Energy and Buildings, 43:179-188.

[37] Goggins J, Keane T, Kelly A (2010) The assessment of embodied energy in typical reinforced concrete building structures in Ireland. Energy and Buildings, 42:735-744. 
[38] Gustavsson L, Joelsson A (2010) Life cycle primary energy analysis of residential buildings. Energy and Buildings, 42:210-220.

[39] Rodriguez Ortiz O, Castells F, Sonnemann G (2010) Life cycle assessment of two dwellings: one in Spain, a developed country, and one in Colombia, a country under development. Science of the Total Environment, 408:2435-2443.

[40] Kofoworola OF, Gheewala SH (2008) Environmental life cycle assessment of a commercial office building in Thailand. The International Journal of Life Cycle Assessment, 13:498-511.

[41] Zhou X, Ge J, Yan Y (2012) Research of CO2 emission of residential buildings in Zhejiang province based on life cycle assessment. Advanced Materials Research, 461:255-258.

[42] Acquaye A, Duffy A, Basu B (2011) Embodied emissions abatement--A policy assessment using stochastic analysis. Energy Policy, 39:429-441.

[43] Abanda FH, Tah JHM, Cheung FKT (2013) Mathematical modelling of embodied energy, greenhouse gases, waste, time-cost parameters of building projects: a review. Building and Environment, 59:23-37.

[44] Omar Wan WMS, Doh JH, Panuwatwanich K (2014) Variations in embodied energy and carbon emission intensities of construction materials. Environmental Impact Assessment Review, 49:3148.

[45] Li DZ, Chen HX, Hui ECM, Zhang JB, Li QM (2013) A methodology for estimating the life-cycle carbon efficiency of a residential building. Building and Environment, 59:448-455.

[46] Hong J, Shen GQ, Feng Y, Lau WST, Mao C (2015) Greenhouse gas emissions during the construction phase of a building: A case study in China. Journal of Cleaner Production, 103:249259.

[47] Mao C, Shen Q, Shen L, Tang L (2013) Comparative study of greenhouse gas emissions between off-site prefabrication and conventional construction methods: Two case studies of residential projects. Energy and Buildings, 66:165176.

[48] Zhang X, Wang F (2016) Assessment of embodied carbon emissions for building construction in China: Comparative case studies using alternative methods. Energy and Buildings, 130:330-340.

[49] Peng C (2016) Calculation of a building's life cycle carbon emissions based on Ecotect and building information modeling. Journal of Cleaner Production, 112:453-465.

[50] Li L, Chen K (2017) Quantitative assessment of carbon dioxide emissions in construction projects: A case study in Shenzhen. Journal of Cleaner Production, 141:394-408.

[51] Yan H, Shen Q, Fan LC, Wang Y, Zhang L (2010) Greenhouse gas emissions in building construction: A case study of One Peking in Hong Kong. Building and Environment, 45:949-955.

[52] Gonzalez MJ, Navarro JG (2006) Assessment of the decrease of $\mathrm{CO} 2$ emissions in the construction field through the selection of materials: Practical case study of three houses of low environmental impact. Building and Environment, 41:902-909.

[53] Dong YH, Jaillon LC, Chu P, Poon C (2015) Comparing carbon emissions of precast and castIn-Situ construction methods-A case study of high-rise private building. Construction and Building Materials, 99:39-53.

[54] Gan VJ, Chan C, Tse K, Lo IM, Cheng JC (2017) A comparative analysis of embodied carbon in high-rise buildings regarding different design parameters. Journal of Cleaner Production, 161:663-675.

[55] Guggemos AA, Horvath A (2005) Comparison of environmental effects of steel-and concrete-framed buildings. Journal of Infrastructure Systems, 11:93-101.

[56] Lee J, Tae S, Kim R (2018) A Study on the analysis of $\mathrm{CO} 2$ emissions of apartment housing in the construction process. Sustainability, 10(2), 365.

[57] Xing S, Xu Z, Jun G (2008) Inventory analysis of LCA on steel-and concrete-construction office buildings. Energy and Buildings, 40:1188-1193.

[58] Kim T, Chae C, Kim G, Jang H (2016) Analysis of $\mathrm{CO} 2$ emission characteristics of concrete used at construction sites. Sustainability, 8(4):348.

[59] Lee S, Park W, Lee H (2013) Life cycle CO2 assessment method for concrete using $\mathrm{CO} 2$ balance and suggestion to decrease $\mathrm{LCCO} 2$ of concrete in South-Korean apartment. Energy and Buildings, 58:93-102.

[60] Cho SH, Chae CU (2016) A study on life cycle $\mathrm{CO} 2$ emissions of low-carbon building in South Korea. Sustainability, 8:579.

[61] Culakova M, Vilcekova S, Burdova EK, Katunska J (2012) Reduction of carbon footprint of building structures. Chemical Engineering Transactions, 29:199-204. 
[62] Ng ST, Wong JMW, Skitmore S, Veronika A (2012) Carbon dioxide reduction in the building life cycle: a critical review. Engineering Sustainability, 165(4):281-292.

[63] Balaras CA, Gaglia AG, Georgopoulou E, Mirasgedis S, Sarafidis Y, Lalas DP (2007) European residential buildings and empirical assessment of the Hellenic building stock, energy consumption, emissions and potential energy savings. Building and Environment, 42(3):12981314.

[64] Gustavsson L, Joelsson A, Sathre R (2010) Life cycle primary energy use and carbon emission of an eight-storey wood-framed apartment building. Energy and Buildings, 42(2):230-242.

[65] Dodoo A, Gustavsson L, Sathre R (2009) Carbon implications of end-of-life management of building materials. Resources, Conservation \& Recycling, 53(5):276-286.

[66] Airaksinen M, Matilainen P (2011) A carbon footprint of an office building. Energies, 4(8):11971210.

[67] Cho S, Na S (2017) The reduction of $\mathrm{CO} 2$ emissions by application of high-strength reinforcing bars to three different structural systems in South Korea. Sustainability, 9:1652.

[68] Buyle M, Braet J, Audenaert A (2013) Life cycle assessment in the construction sector: a review. Renewable \& Sustainable Energy Reviews, 26:379-388.

[69] Malmqvist T, Glaumann M, Scarpellini S, Zabalza I, Aranda A, Llera E, Díaz S (2011) Life cycle assessment in buildings: the ENSLIC simplified method and guidelines. Energy 36:1900-1907.

[70] Karami P, Al-Ayish N, Gudmundsson K (2015) A comparative study of the environmental impact of Swedish residential buildings with vacuum insulation panels. Energy and Buildings, 109:183194.

[71] Basbagill J, Flager F, Lepech M, Fischer M (2013) Application of life-cycle assessment to early stage building design for reduced embodied environmental impacts. Building and Environment, 60:81-92.

[72] Dakwale VA, Ralegaonkar RV, Mandavgane S (2011) Improving environmental performance of building through increased energy efficiency: a review. Sustainable Cities and Society, 4:211-218.

[73] Ansah MK, Chen X, Yang H, Lu L, Lam PTI (2020) An integrated life cycle assessment of different facade systems for a typical residential building in Ghana. Sustainable Cities and Society, 53:101974.

[74] Cabeza LF, Rincón L, Vilariño V, Pérez G, Castell A (2014) Life cycle assessment (LCA) and life cycle energy analysis (LCEA) of buildings and the building sector: A review. Renewable and Sustainable Energy Reviews, 29:394-416.

[75] Mearig T, Coffee N, Morgan M. Life Cycle Cost Analysis Handbook: State of Alaska, Department of Education and Early Development ( $2^{\text {nd }}$ Edition), 2018.

[76] ISO, ISO 14040, Environmental Management-Life Cycle Assessment-Principles and Framework, International Organization for Standardization. 1997.

[77] U.S. Environmental Protection Agency. Emission Facts: Average Carbon Dioxide Emissions Resulting from Gasoline and Diesel Fuel. http://www.epa.gov/otaq/climate/420f05001.htm\# calculating

[78] Chau CK, Hui WK, Ng WY, Powell G (2012) Assessment of $\mathrm{CO} 2$ emissions reduction in highrise concrete office buildings using different material use options. Resources, Conservation and Recycling, 61:22-34.

[79] Yousheng Z. Life cycle assessment on the reduction of carbon dioxide emission of buildings, Doctoral Dissertation, National Cheng Kung University, 2002.

[80] Intergovernmental Panel on Climate Change. IPCC guidelines for national greenhouse gas inventories. Energy 2006; 2. http://www.ipccnggip.iges.or.jp/public/2006gl/vol2.html.

[81] Tian YW, Zhao Q, Jian G et al. Study on the lifecycle carbon emission and energy efficiency management of the large-scale public buildings in Hangzhou, China. International Conference on Computer and Management (CAMAN), 19-21 May 2011, Wuhan, China.

[82] Varun, Sharma A, Shree V, Nautiyal H (2012) Life cycle environmental assessment of an educational building in Northern India: A case study. Sustainable Cities and Society, 4:22-28.

[83] Zhang X, Wang F (2015) Life-cycle assessment and control measures for carbon emissions of typical buildings in China. Building and Environment, 86:89-97.

[84] Bangladesh Power Development Board, https://www.bpdb.gov.bd/

[85] Moazzem DG. The Power Sector in the National Budget for FY2020-21: An Analysis of Allocative 
Priorities \& Alternate Proposals. Centre for Policy Dialogue (CPD). 24 June, 2020.

[86] Weldu YW, Assefa G, Jolliet O (2017) Life cycle human health and ecotoxicological impacts assessment of electricity production from wood biomass compared to coal fuel. Applied Energy, 187:564-574.

[87] Khan I, Jack MW, Stephenson J (2018) Analysis of greenhouse gas emissions in electricity systems using time-varying carbon intensity. Journal of Cleaner Production, 184:1091-1101.

[88] Song Q, Wang Z, Li J, Duan H, Yu D, Liu G (2018) Comparative life cycle GHG emissions from local electricity generation using heavy oil, natural gas, and MSW incineration in Macau. Renewable and Sustainable Energy Reviews, 81:2450-2459.

[89] Karmaker AK, Rahman MM, Hossain MA, Ahmed MR (2020). Exploration and corrective measures of greenhouse gas emission from fossil fuel power stations for Bangladesh. Journal of Cleaner Production, 244:118645.
[90] Hasan MM, Chongbo W (2020) Estimating energyrelated $\mathrm{CO} 2$ emission growth in Bangladesh: The LMDI decomposition method approach. Energy Strategy Reviews, 32:100565.

[91] Ardente F, Beccali M, Cellura M, Mistretta M (2008) Building energy performance: A LCA case study of kenaf-fibres insulation board. Energy and Buildings, 40:1-10.

[92] Islam H, Jollands M, Setunge S, Ahmed I, Haque N (2014) Life cycle assessment and life cycle cost implications of wall assemblage's designs. Energy and Buildings, 84:33-45.

[93] Gong XZ, Nie ZR, Wang ZH, Cui SP, Gao F, Zuo TY (2012) Life cycle energy consumption and carbon dioxide emission of residential building designs in Beijing: A Comparative Study. Journal of Industrial Ecology, 16(4):576-587.

[94] Yu D, Tan H, Ruan Y (2011) A future bamboostructure residential building prototype in China: Life cycle assessment of energy use and carbon emission. Energy and Buildings, 43:2638-2646. 